ПІДВИЩЕННЯ

КОНКУРЕНТО-

СПРОМОЖНОСТI

ВІТЧИЗНЯНИХ

ПІДПРИЕМСТВ

СЕГМЕНТУ

МІЖНАРОДНИХ

ВАНТАЖНИХ

АВТОПЕРЕВЕЗЕНЬ
ДМИТРІВ Д.В., кандидат технічних наук, доцент, завідувач кафедри економічної кібернетики

ДМИТРІВ О.Р., кандидат технічних наук, доцент кафедри автоматизації технологічних процесів і виробництв

\author{
ДЕНКЕВИЧ М-М.М., \\ магістрантка першого року навчання \\ факультету економіки та менеджменту, \\ Тернопільський національний технічний \\ університет імені Івана Пулюя \\ (м. Тернопіль)
}

Розвиток сучасної транспортної системи пов'язаний із загостренням конкурентної боротьби на тлі циифровізації транспортних процесів, щуо вимагає від вітчизняних автоперевізників знаходити ефективні методи підвищення власної конкурентоспроможності на міжнародному ринку транспортних послуг.

Стаття присвячена пошуку шляхів підвищення конкурентоспроможності вітчизняних автотранспортних підприємств у сегменті міжнародних вантажних автомобільних перевезень. Розглянуто наукові підходи тлумачення терміну «конкурентоспроможність автотранспортних підприємств» із поглядів маркетингу, управління, ресурсного забезпечення та прибутковості. На підставі проведеного огляду запропоновано бачення конкурентоспроможності автотранспортних підприємств $у$ сегменті міжнародних вантажних перевезень. Висвітлено наукові дослідження, присвячені впливу управлінських, маркетингових логістичних методів на конкурентоспроможність автотранспортних підприємств. Проведено порівняння наукових поглядів на вибір та групування чинників впливу на конкурентоспроможність вітчизняних автопідприємств та запропоновано групування чинників впливу на конкурентоспроможність за можливістю їхньої кількісної оцінки. Охарактеризовано існуючі методики оцінки конкурентоспроможності автотранспортних підприємств. Досліджено сучасні тенденціі впровадження цифрових технологій у діяльність транспортних систем та доведено необхідність їх запровадження у діяльність вітчизняних автотранспортних підприємств, щзо здійснюють міжнародні вантажні перевезення. Сформульовано базові проблеми, які гальмують впровадження сучасних изифрових технологій у діяльність вітчизняних підприємств на ринку міжнародних вантажних автоперевезень. Запропоновано иляхи підвищення конкурентоспроможності автопідприємств, які перевозять вантажі в міжнародному сполученні у сучасних умовах ведення бізнесу.

Ключові слова: конкурентоспроможність, автотранспортне підприємство, міжнародні вантажні автомобільні перевезення, транспортно-логістичні технології, цифрові технології, інформаційно-комунікаційні системи.

Табл.: 2. Літ.: 21. 


\title{
INCREASING THE COMPETITIVENESS OF DOMESTIC ENTERPRISES IN THE SEGMENT OF INTERNATIONAL ROAD FREIGHT TRANSPORT
}

\author{
DMYTRIV Dmytro, \\ Candidate of Technical Sciences, Associate Professor, \\ Head of the Department of Economic Cybernetics
}

\author{
DMYTRIV Olena, \\ Candidate of Technical Sciences, \\ Associate Professor of the Department of Automation of \\ Technological Processes and Production \\ DENKEVYCH Mariia-Mariana, \\ First Year Master's Student \\ Faculty of Economics and Management \\ Ternopil Ivan Puluj National Technical University
} (Ternopil)

The development of modern transport system connected with intensification of competitive struggle against the background of digitalization of transport processes requires domestic road carriers to find effective methods of increasing their own competitiveness in the international market of transport services.

The article is devoted to the ways of increasing the competitiveness of domestic road transport enterprises in the segment of international road freight transport. Scientific approaches of interpretation of the term competitiveness of motor transport enterprises in terms of marketing, management, resource provision and profitability are considered. On the basis of the conducted review, a vision of competitiveness of motor transport enterprises in the segment of international cargo transportation is offered. Scientific researches devoted to the influence of management, marketing logistic methods on the competitiveness of motor transport enterprises are highlighted. The authors have compared scientific views on the choice and grouping of the factors of influence on the competitiveness of domestic motor transport enterprises and have offered the grouping of factors of influence on the competitiveness according to the possibility of their quantitative assessment. Existing methods for assessing the competitiveness of road transport enterprises were characterized. Modern tendencies of digital technologies implementation in transport systems activity have been investigated and the necessity of their implementation in the activity of domestic motor transport enterprises in the segment of international motor cargo transportations has been proved. The basic problems that hinder the implementation of modern digital technologies in the activities of domestic enterprises in the segment of international road freight transport haulage are formulated. Ways of improving the competitiveness of domestic enterprises in the segment of international road freight transport in today's business environment have been proposed.

Key words: competitiveness, road transport enterprise, international road freight transport, transport and logistics technology, digital technology, information and communication systems.

Table: 2. Lit.: 21.

\section{ПОВЫШЕНИЕ КОНКУРЕНТОСПОСОБНОСТИ ОТЕЧЕСТВЕННЫХ ПРЕДПРИЯТИЙ СЕГМЕНТА МЕЖДУНАРОДНЫХ ГРУЗОВЫХ АВТОПЕРЕВОЗОК}


ДМЫТРИВ Д.В., кандидат технических наук, доцент, заведующий кафедрой экономической кибернетики

\author{
ДМЫТРИВ А.Р., \\ кандидат технических наук, \\ доцент кафедры автоматизации технологических \\ процессов и производств
}

ДЕНКЕВИЧ М-М.М., магистрантка первого года обучения факультета економики и менеджмента, Тернопольский национальный технический университет имени Ивана Пулюя

\begin{abstract}
Развитие современной транспортной системы связанной с обострением конкурентной борьбы на фоне ичирровизации транспортных прочессов, требует от отечественных автоперевозчиков находить эффективные методы повышения собственной конкурентоспособности на международном рынке транспортных услуг.

Статья посвящена поиску путей повышения конкурентоспособности отечественных автотранспортных предприятий в сегменте международных грузовых автомобильных перевозок. Рассмотрены научные подходы толкования термина конкурентоспособность автотранспортных предприятий с точки зрения маркетинга, управления, ресурсного обеспечения и прибыльности. На основании проведённого обзора, предложено видение конкурентоспособности автотранспортных предприятий в сегменте международных грузовых перевозок. Освещчены научные исследования, посвященные влиянию управленческих, маркетинговых логистических методов на конкурентоспособность автотранспортных предприятий. Проведено сравнение научных взглядов на выбор и группирование факторов влияния на конкурентоспособность отечественных автопредприятий и предложено группирование факторов влияния на конкурентоспособность по возможности их количественной оценки. Охарактеризовань существуюшие методики оценки конкурентоспособности автотранспортных предприятий. Исследованы современные тенденции внедрения ичифровых технологий в деятельность транспортных систем $u$ доказана необходимость их внедрения в деятельность отечественных автотранспортных предприятий, которые осуществляют международные грузовые перевозки. Сформулированы базовые проблемы, которые тормозят внедрение современных ичифровых технологий в деятельность отечественных предприятий на рынке международных грузовых автоперевозок. Предложены пути повышения конкурентоспособности отечественных автопредприятий, которые перевозят грузы в международном сообщении в современных условиях ведения бизнеса.
\end{abstract}

Ключевые слова: конкурентоспособность, автотранспортное предприятие, международные грузовые автомобильные перевозки, транспортно-логистические технологии, цифровые технологии, информационно-комуникационные системы.

Табл.: 2. Лит.: 21.

Постановка проблеми. Українські автотранспортні підприємства (далі АТП) у сегменті міжнародних вантажних автомобільних перевезень (далі МВАП) через брак фінансових ресурсів знаходяться у гіршому конкурентному 
положенні порівняно зі своїми іноземними колегами. Тому вітчизняним перевізникам необхідно активно запроваджувати інновації, які дозволять частково урівноважити позиції у конкурентній боротьбі. Крім цього, у Транспортній стратегії України на період до 2030 року [20] зазначено, що транспортна система України володіє низьким рівнем розвитку транспортнологістичних технологій, що значно знижує іiі конкурентоспроможність та обмежує вихід вітчизняних перевізників на глобальний транспортний ринок.

Аналіз останніх досліджень і публікацій. Питанням функціонування та забезпечення конкурентоспроможності автотранспортних підприємств, у т.ч. у сегменті міжнародних вантажних перевезень, присвячені наукові праці ряду вітчизняних вчених. На рівні макросередовища: Дяченко Т.О. дослідила конкурентоспроможність автотранспортних підприємств та стратегіï іiі підвищення [4], Козіна К.Г. проводила дослідження ринку міжнародних вантажних автомобільних перевезень [9], Яновська В.П. охарактеризувала особливості формування стратегії розвитку національних автотранспортних перевізників [21]. Чинники впливу на рівні мікросередовища розкриті у працях Мітченко Г.В., яка вивчала стратегічний маркетинг на АТП [13], Кіндій М.В., яка висвітлила чинники, що впливають на тарифи перевезень [8], Железняк К.Л., яка детально описала механізм просування транспортних послуг [6], а також Аберніхіної І.Г., яка свої дослідження присвятила забезпеченню рентабельності АТП [1]. Однак, із об'єктивних причин у зазначених наукових доробках відсутні розробки щодо впливу сучасних викликів, а саме: економічної кризи, пандемії та цифрової економіки на діяльність та конкурентоспроможність вітчизняних АТП у сегменті МВАП.

Формулювання цілей статті. Метою дослідження $\epsilon$ комплексне вивчення теоретичних підходів до забезпечення конкурентоспроможності АТП та методів іiї оцінки. На підставі проведених досліджень запропонувати шляхи підвищення конкурентоспроможності вітчизняних АТП у сегменті МВАП.

Виклад основного матеріалу дослідження. Як доводить експертне середовище $[17$, с. 62$]$, використання транспортно-логістичних систем зменшує загальні витрати транспортування на $12-35 \%$, у т.ч. транспортні витрати - на 7-20\%, витрати на виконання навантажувально-розвантажувальних робіт - на $15-30 \%$ [17, с. 62]. Слід зауважити, що цифровізація комплексу транспортнологістичних процесів МВАП на вітчизняних АТП відбувається дуже повільно, що загалом негативно відбивається на їх конкурентоспроможності. 3 метою детального дослідження, яким чином підвищувати конкурентоспроможність вітчизняних АТП у сегменті МВАП, проведемо огляд підходів до тлумачення терміну конкурентоспроможність АТП.

Загалом, конкурентоспроможність підприємства $є$ його спроможністю створювати, виробляти і продавати товари та послуги, цінові й нецінові якості яких привабливіші, ніж в аналогічної продукції конкурентів [3]. Тому доцільно розглядати конкурентоспроможність підприємства 3 точки зору порівняльної переваги відносно аналогічних підприємств однієї галузі економіки.

У застосуванні до автотранспортних підприємств, слід враховувати притаманні їм ознаки, серед яких виділяють [12, с. 14]: 
- відносність поняття, оцінки та вимірювання конкурентоспроможності;

- відповідність оціночних показників конкурентоспроможності до стану ринку, наявних умов та часу реалізації транспортних послуг;

- споживча корисність транспортної послуги, яка надається, під час оцінки конкурентоспроможності.

У своїх дослідженнях Козіна І.Г. систематизувала погляди вітчизняних науковців на визначення конкурентоспроможності автотранспортних підприємств [10, с. 49]. У таблиці 1 наведена дана систематизація з авторським доповненням.

Таблиия 1

\section{Тлумачення поняття «конкурентоспроможність автотранспортного} підприємства»

\begin{tabular}{|c|c|c|}
\hline № & ПІП & Визначення поняття \\
\hline 1 & Дяченко Т.О. [4, с. 7] & $\begin{array}{cccc}\text { Здатність підприємства прибутково завойовувати } & \text { сегмент } & \text { ринку } \\
\text { транспортних послуг та утримуватись на ньому. }\end{array}$ \\
\hline 2 & Козіна К.Г. [10, с. 49] & $\begin{array}{l}\text { Системна здатність АТП доцільно використовувати свої конкурентні } \\
\text { переваги на конкретному ринку, ще забезпечує задоволення } \\
\text { платоспроможного попиту споживачів } 3 \text { максимально корисним ефектом, } \\
\text { продуктивне функціонування підприємства порівняно з конкурентами та його } \\
\text { усталений розвиток. }\end{array}$ \\
\hline 3 & Жовновач Р.І. [7, с 151] & $\begin{array}{l}\text { Спроможність забезпечувати пропозицію транспортних послуг найкращим } \\
\text { чином, у порівнянні } 3 \text { конкурентами, задовольняти вимоги різних сегментів } \\
\text { транспортного ринку } 3 \text { дотриманням стандартів якості підприємства та } \\
\text { стандартів галузі. }\end{array}$ \\
\hline 4 & Борисюк I.O. [2, с. 7] & $\begin{array}{l}\text { Система взаємозалежних елементів, що складається з внутрішнього } \\
\text { середовища підприємства, його споживачів і конкурентів, об'єднаних у єдине } \\
\text { ціле } 3 \text { метою вирішення задачі забезпечення міцних конкурентних позицій, } \\
\text { збереження інуючих і нарощування нових конкурентних переваг. }\end{array}$ \\
\hline
\end{tabular}

Джерело: узагальнено та доповнено авторами на основі опраџьованих джерел

Отже, узагальнюючи погляди вчених та враховуючи специфіку діяльності АТП у сегменті МВАП, під конкурентоспроможністю таких підприємств будемо розуміти спроможність АТП надавати транспортні послуги на міжнародному ринку з дотриманням міжнародних стандартів якості, цінові та нецінові характеристики яких привабливіші, ніж послуги конкурентів, нарощувати власний сегмент ринку із забезпеченням зростання прибутковості.

На думку Понаморьової Н.М. [18, с. 198], ймовірність виграшу конкурентної боротьби вітчизняних АТП у сегменті МВАП буде зростати, якщо вони будуть пропонувати кращий набір корисностей із позитивним економічним ефектом споживача послуг. Базуючись на гіпотезі того, що на ринку транспортних послуг конкурують не окремі автотранспортні підприємства, а ланцюги постачання вантажу з врахуванням посередників, було запропоновано модель «карти клієнтозабезпеченності АТП» [18, с. 199]. Запропоновану модель, можна використовувати 3 метою ранжування клієнтської бази конкретних АТП у сегменті МВАП за кількісними параметрами у разі використання програмних продуктів інформаційнихкомунікаційних систем (далі - IКС).

Враховуючи базові характеристики, які $\epsilon$ важливими споживачеві 
транспортних послуг, а саме їх вартість, якість, швидкість та номенклатура, Пономарьов А.М. [16, с. 47], запропонував структуру логістики та маркетингу, які забезпечують конкурентну позицію АТП. Також автором було запропоновано математичну модель визначення найбільш важливих параметрів послуг МВАП до вимог потенційних споживачів. Елементи запропонованої моделі можна використовувати під час написання відповідного програмного продукту.

Із метою визначення оціночних характеристик конкурентоспроможності вітчизняних АТП у сегменті МВАП, необхідно дослідити чинники, які впливають на неї. У цьому аспекті, досить детально чинники впливу на конкурентоспроможність перелічені у праці [19, с. 356], а оскільки їх кількість доволі значна, автор згрупував їх за певними ознаками. Однак, запропоноване групування чинників не в достатній мірі систематизоване стосовно логічного поділу на чинники внутрішнього та зовнішнього середовища. Такий поділ у систематизації чинників впливу на конкурентоспроможність вітчизняних АТП у сегменті МВАП, представлено у праці [11, с. 204].

Але, на нашу думку, серед запропонованих і систематизованих чинників, доцільно приділити більшу увагу тим чинникам, які піддаються кількісному вимірюванню (табл. 2).

Таблиия 2

Чинники впливу на конкурентоспроможність вітчизняних АТП у сегменті MBAП

\begin{tabular}{|c|c|c|}
\hline & Внутрішні чинники & Зовнішні чинники \\
\hline \multirow{6}{*}{ 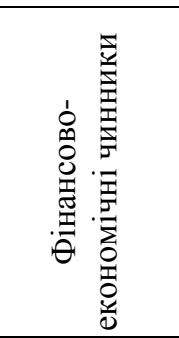 } & Плановий обсяг перевезень АТП & Вартість митних послуг \\
\hline & $\begin{array}{l}\text { Максимально можливий обсяг перевезень } \\
\text { АТП }\end{array}$ & Вартість паливо-мастильних матеріалів \\
\hline & Собівартість транспортних послуг (ТП) & $\begin{array}{l}\text { Кількість дозволів на здійснення міжнародних } \\
\text { рейсів }\end{array}$ \\
\hline & Вартість ТП & Податкові збори \\
\hline & Рентабельність ТП & Вартість віз \\
\hline & Прибуток АТП & Величина відсотків за кредити \\
\hline \multirow{5}{*}{ 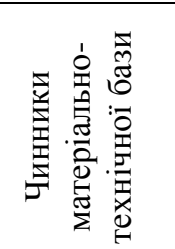 } & Кількість АРМ та програмних продуктів & Допустима експлуатаційна вага вантажівок \\
\hline & $\begin{array}{l}\text { Кількість вантажівок за нормами екологічної } \\
\text { чистоти EURO }\end{array}$ & $\begin{array}{l}\text { Кількість пального, що допускається мати на } \\
\text { кордоні }\end{array}$ \\
\hline & Кількість причепів за спеціалізацією вантажів & Кількість заправних станцій на 100 км \\
\hline & Кількість ділянок технічного обслуговування & Кількість пунктів харчування на 100 км \\
\hline & Кількість вантажівок за тоннажем & Кількість стоянок на 100 км \\
\hline \multirow{3}{*}{ 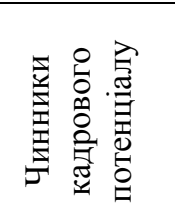 } & Кількість водіїв & Кількість брокерів \\
\hline & Кількість обслуговуючого персоналу & Кількість митників у пункті пропуску \\
\hline & $\begin{array}{l}\text { Кількість персоналу, що п підвищує } \\
\text { кваліфікацію }\end{array}$ & Кількість конкурентів \\
\hline \multirow{3}{*}{ 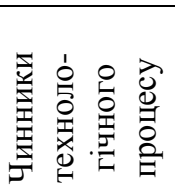 } & Тривалість транспортного циклу & Нормативний час відпочинку водія \\
\hline & Середня швидкість руху вантажівки & Середній час простою на митниці \\
\hline & Тривалість підготовки вантажівки до рейсу & $\begin{array}{l}\text { Кількість святкових днів в інших країнах, коли } \\
\text { рух заборонений }\end{array}$ \\
\hline
\end{tabular}

Джерело: розробено авторами

До прикладу, складно оцінити вплив на діяльність вітчизняних АТП у сегменті МВАП ймовірності настання позитивних чи негативних явищ 
геополітики, які відносяться до чинників зовнішнього середовища, 3 іншого боку можна прогнозувати кількість виділених дозволів на здійснення міжнародних рейсів. У запропонованій таблиці чинники згруповані як за поділом на внутрішні та зовнішні, так і за приналежністю до фінансовоекономічних, технологічних, матеріально-технічних та кадрових елементів системи організації МВАП. Рекомендоване групування чинників можна розширювати як із огляду на особливості діяльності конкретного АТП, так і 3 огляду на детальну обробку числових даних процесу перевезень у міжнародному сполученні.

У праці [5, с. 101], оцінку конкурентоспроможності АТП рекомендують здійснювати у кілька етапів, а саме:

- виявлення основних конкурентів;

- збирання даних щодо діяльності конкурентів;

- підбір оцінювальних показників,

- аналіз зібраної інформації;

- отримання загального показника конкурентоспроможності.

Також, пропонується проводити оцінку конкурентоспроможності за допомогою матричних, індексних та графічних методів [5, с. 103].

Слід зауважити, що проведення комплексної оцінки конкурентоспроможності АТП у сегменті МВАП, супроводжується обробкою великих масивів інформаційних даних, які повинні підлягати перевірці та уточненню різними, у т.ч. математичними методами, що дозволить збільшити точність порівняльних розрахунків. А також доцільно чисельно враховувати взаємозв'язки (взаємовпливи) управлінських, логістичних, маркетингових та інших чинників забезпечення необхідного рівня конкурентоспроможності АТП у сегменті МВАП.

Прикладом обробки інформаційних масивів маркетингової складової, щодо забезпечення оптимального управління конкурентоспроможністю АТП у сегменті МВАП, може бути маркетингова інформаційна система (MAIC), яка складається 3 масиву даних (дані про АТП і його середовище), банку методів (набір математичних методів), банку моделей (набір кількісних моделей маркетингу) і комунікаційної системи (програмні продукти, які забезпечують функціонування системи).

Оскільки сьогодні ми переживаємо четверту індустріальну революцію, яка характеризується злиттям автоматизованих виробництв, виробничих технологій та обміном даних у глобальну саморегульовану систему, це неодмінно змінить функціонування транспортних систем, до яких відносяться об'єкти досліджень даної статті. Тому, враховуючи попередні теоретичні викладки та нові тенденції розвитку транспортно-логістичних систем, необхідно дослідити інноваційні заходи, які забезпечать конкурентоспроможність вітчизняних АТП у сегменті МВАП у довгостроковій перспективі. Одним із таких сучасних заходів $\epsilon$ розробка, активне впровадження і використання цифрових технологій у діяльності вітчизняних АТП у сегменті МВАП, однак у цьому процесі виникає ряд проблем.

Перша проблема полягає у тому, що запровадження цифрових технологій 
передбачає прозорість фінансово-господарських процесів, до якої власники АТП ставляться упереджено, боячись витоків комерційних таємниць. Отже, це породжує другу проблему - відсутність співпраці власників АТП із фахівцями IT-галузі, спроможними розробляти сервісні програмні продукти процесу перевезень. Третьою проблемою можна назвати спеціалізацію інформаційних систем під вимоги конкретних АТП, які складно піддаються інтегруванню. Четверта проблема пов'язана 3 недостовірністю інформації, яка розміщується на відомих сайтах інтеграції інтересів споживачів та надавачів транспортних послуг. П'ята проблема полягає у дефіциті фахівців, здатних працювати 3 сучасними програмними продуктами транспортно-логістичних систем. Цей перелік можна продовжувати, але незаперечним фактом $є$ те, що на фоні обмежених фінансових ресурсів у вітчизняних АТП сегменту МВАП, оптимізувати статті витрат можна за рахунок використання саме цифрових технологій. Підтвердженням перспективності цифровізації функціоналу вітчизняних АТП у сегменті МВАП є те, що в європейських країнах цифрові технології на автомобільному транспорті, нині не стандартизовані та не використовуються в повній мірі [21, с. 97].

На думку фахівців $[14$, с. 71], складова транспорту в Індустрії 4.0 буде пов'язана з активним запровадженням інноваційних процесів цифровізації:

- поширення концепції мережі - Інтернет речей;

- застосування хмарних обчислень та великих даних;

- автоматизація та роботизація операцій на транспорті;

- комунікація краудсорсинг;

- використання технології блокчейн у логістиці.

Одним із прикладів застосування цифрових технологій на транспорті можна назвати технології компанії Uber Technologies Inc, принципи яких можна рекомендувати до запровадження на вітчизняних АТП у сегменті МВАП.

$\mathrm{У}$ роботі $[15$, с. 62$]$ запропоновано оцінювати цифровізацію транспортної галузі України за системою індикаторів, яка включає оцінку кваліфікованих кадрів, активності використання мережі інтернет, інтенсивності запровадження цифрових технологій та використання програмних продуктів, сумарних витрат на використання інформаційно-комунікаційних технологій. Застосування такої системи індикаторів дозволить статистично оцінювати рівень цифровізації у т.ч. вітчизняних АТП у сегменті МВАП.

Узагальнюючи, можна рекомендувати наступні шляхи підвищення конкурентоспроможності вітчизняних підприємств сектору міжнародних вантажних автоперевезень у сучасних умовах господарювання:

1) сформувати базу даних оціночних показників конкурентів, особливо 3 числа іноземних компаній;

2) провести аналіз даних та за допомогою апарату математичного моделювання, провести розрахунки прогнозних значень показників прибутковості;

3) використовуючи інструментарій маркетингу, дослідити та сформувати цільову клієнтську базу;

4) підвищувати рівень фаховості керівного складу АТП щодо 


\section{ЕФМ \\ http://efm.vsau.org/}

необхідності запровадження і використання у своїй діяльності цифрових технологій;

5) адміністрації АТП у сегменті МВАП проводити якісну роботу щодо підвищення ділової репутації;

6) керівництву АТП у сегменті МВАП організовувати роботу 3 підвищення кваліфікації персоналу щодо цифрової грамотності, у т.ч. із метою використання переваг сервісів електронного надання адміністративних послуг;

7) керівництву АТП у сегменті МВАП використовувати навігаційні супутникові системи та технології навігації, поводити покроковий аналіз процесів доставки вантажів;

8) керівництву Асоціації міжнародних автомобільних перевезень (далі АСМАП), спільно з фахівцями ІТ-галузі, організувати розробку інформаційної платформи оптимального управління транспортним процесом, яка буде доступною для вітчизняних АТП у сегменті МВАП. Проєктні програмні продукти повинні бути функціональними та надійними;

9) керівництву АСМАП контролювати дотримання всіма членами асоціації етичних правил ведення бізнесу;

10) власникам сайтів, де публікуються оголошення про транспортні послуги, провести ревізію клієнтської бази на предмет достовірності інформації та платоспроможності.

Висновки. Забезпечення конкурентоспроможності
транспортної системи на ринку міжнародних вантажних перевезень
обумовлюється рівнем конкурентних переваг ¥і учасників. Оскільки обумовлюється рівнем конкурентних переваг і1 учасників. Оскільки вітчизняним автоперевізникам складно конкурувати з іноземними колегами на рівні масового оновлення автопарку та суміжного технологічного обладнання, необхідно застосовувати інші заходи що забезпечать мінімізацію витрат. У цьому контексті дієвим заходом для вітчизняних автоперевізників може стати запровадження цифрових технологій на всіх стадіях виконання перевізного циклу. Відповідно, розробка і запровадження таких технологій і відповідних програмних продуктів, може забезпечуватись за умов введення у вихідні дані кількісних показників транспортного процесу. Мінімізація витрат, пов'язаних із забезпеченням оптимальних показників транспортного циклу, дозволить підвищити конкурентоспроможність вітчизняних АТП у сегменті МВАП.

\section{Список використаних джерел}

1. Аберніхіна І.Г., Валенюк Н.В., Суботіна Г.О. Підвищення рентабельності підприємства галузі автомобільних перевезень за напрямами комерційної діяльності. Наука та прогрес транспорту. Вісник Дніпропетровського національного університету залізничного транспорту імені академіка В. Лазаряна. 2018. № 2. С. 18-30.

2. Борисюк I.О., Мельник К.О. Управління конкурентоспроможністю автотранспортного підприємства. Modern Economics. 2018. № 12. C. 6-11.

3. Должанський I.3., Загорна Т.О. Конкурентоспроможність підприємства: навчальний посібник. Київ: Центр навчальної літератури, 2006. $384 \mathrm{c}$. 
4. Дяченко Т.О. Визначення конкурентоспроможності автотранспортних підприємств та стратегії іiі підвищення: автореф. дис. ... канд. екон. наук: 08.07.04. Київ: Національний авіаційний університет Міністерства освіти і науки України. 2002. 22 с.

5. Дяченко Т.О., Сєдой В.Г. Методичні аспекти оцінки конкурентоспроможності автотранспортних підприємств. Причорноморські економічні студї. 2019. Вип. 40. С. 99-106.

6. Железняк К.Л. Механізм формування стратегії просування транспортних послуг підприємств : автореф. дис. ... канд. екон. наук: 08.00.04. Київ: Національний транспортний університет, 2015. 20 с.

7. Жовновач P.I. Управління конкурентоспроможністю підприємств сільськогосподарського машинобудування: дис. ... д-ра ек. наук: 08.00.04. Міністерство освіти i науки України, ДВНЗ «Приазовський державний технічний університет». Маріуполь, 2016. 462 с.

8. Кіндій М.В., Малиш Я.В. Чинники та їх вплив на формування тарифів на міжнародні вантажні автомобільні перевезення. Вісник Національного університету «Львівська політехніка». Логістика. 2014. № 811. С. 156-161.

9. Козіна К.Г. Аналіз ринку міжнародних автотранспортних вантажних перевезень: сучасний стан та перспективи розвитку. Науковий вісник Міжнародного гуманітарного університету. Серія : Економіка і менеджмент. 2015. Вип. 10. С. 134-138.

10. Козіна К.Г. Оцінювання стану та розвиток регіональних ринків вантажних автотранспортних перевезень : дис. канд. екон. наук: 08.00.05. Державний ВНЗ «Прикарпатський національний університет ім. Василя Стефаника». Івано-Франківськ, 2020. 240 с.

11. Козіна К.Г. Теоретико-методичні основи факторного аналізу конкурентоспроможності міжнародних автотранспортних вантажних перевезень України. Науковий вісник Херсонського державного університету. Серія: Економічні науки. 2014. Вип. 6(2). С. 203-206.

12. Максюта М.C., Дяченко Т.О. Особливості управління конкурентоспроможністю на транспортних підприємствах. Інноваиійні рішення в сучасній науиі, освіті та практиці: Матеріали I Міжнародної науковопрактичної інтернет-конференції (наукове видання), 17-18 листопада 2020 р.: у 2 ч. Київ: НТУ, 2020. Ч.1. С. 216-219.

13. Мітченко Г.В. Організаційно-економічне забезпечення стратегічного маркетингу на підприємствах автомобільного транспорту : дис. канд. екон. наук : 08.00.04 / Національний транспортний університет. Київ: НТУ, 2015. 211 с.

14. Никифорук О.І., Стасюк О.М., Чмирьова Л.Ю., Федяй Н.О. Цифровізація в транспортному секторі: тенденції та індикатори розвитку. Частина 1. Статистика Украӥни. 2019. № 3. С. 70-81.

15. Никифорук О.І., Стасюк О.М., Чмирьова Л.Ю., Федяй Н.О. Цифровізація в транспортному секторі: тенденції та індикатори розвитку. Частина 2. Статистика Украӥни. 2019. № 4. С. 48-64.

16. Пономарьов А. М. Визначення основних параметрів маркетингу та логістики при функціонуванні АТП на ринку міжнародних вантажних 


\section{ЕФМ \\ http://efm.vsau.org/}

перевезень. Проблеми і перспективи розвитку підприємництва. 2012. № 2. C. 45-49.

17. Пономарьова Н. М., Пономарьов А. М. Теоретичні аспекти аутсорсингу у сфері міжнародних автомобільних вантажних перевезень. Проблеми і перспективи розвитку підприємництва. 2012. № 1. С. 61-65.

18. Пономарьова Н.M., Пономарьов А.М. Формування механізму взаємодії автотранспортного підприємства із суб`єктами ринку міжнародних вантажних перевезень. Маркетинг i менеджмент інновацій. 2011. № 4 (1). C. 196-201.

19. Сніжко Л.Л., Главацький П.В. Визначення та оцінка чинників, що впливають на рівень конкурентоспроможності українських підприємств в сфері міжнародних автомобільних перевезень. Управління проектами, системний аналіз і логістика. Технічна серія. 2011. Вип. 8. С. 354-359.

20. Транспортна стратегія України на період до 2030 року. URL: https://zakon.rada.gov.ua/laws/show/430-2018-\%D1\%80\#Text (дата звернення: 16.05.2021).

21. Яновська В.П., Кириченко Г.В. Особливості формування стратегії розвитку національних автотранспортних перевізників. Менеджмент та підприємництво в Україні: етапи становлення та проблеми розвитку. 2020. Вип. 2, № 2. С. $92-108$.

\section{References}

1. Abernikhina, I.Gh., Valenjuk, N.V., \& Subotina, Gh.O. (2018). Pidvyshhennja rentabeljnosti pidpryjemstva ghaluzi avtomobiljnykh perevezenj za naprjamamy komercijnoji dijaljnosti [Increasing the profitability of the enterprise in the field of road transport in the areas of commercial activity]. Nauka ta proghres transportu. Visnyk Dnipropetrovsjkogho nacionaljnogho universytetu zaliznychnogho transportu imeni akademika V. Lazarjana - Science and progress of transport. Bulletin of Dnipropetrovsk National University of Railway Transport named after Academician V. Lazaryan, 2, 18-30 [in Ukrainian].

2. Borysjuk, I.O., \& Meljnyk, K.O. (2018). Upravlinnja konkurentospromozhnistju avtotransportnogho pidpryjemstva [Management of competitiveness of the motor transport enterprise]. Modern Economics, 12, 6-11 [in Ukrainian].

3. Dolzhansjkyj, I.Z., \& Zaghorna, T.O. (2006). Konkurentospromozhnistj pidpryjemstva [Competitiveness of the enterprise]. Kyiv: Centr navchaljnoji literatury [in Ukrainian].

4. Djachenko, T.O. (2002). Vyznachennja konkurentospromozhnosti avtotransportnykh pidpryjemstv ta strateghiji jj pidvyshhennja [Determining the competitiveness of motor transport enterprises and strategies to increase it]. Extended abstract of candidate's thesis. Kyiv: Natsionalnyi aviatsiinyi universytet Ministerstva osvity i nauky Ukrainy [in Ukrainian].

5. Djachenko, T.O., \& Sjedoj, V.Gh. (2019). Metodychni aspekty ocinky konkurentospromozhnosti avtotransportnykh pidpryjemstv [Methodological aspects of assessing the competitiveness of motor transport enterprises]. Prychornomorsjki 
ekonomichni studiji - Black Sea Economic Studies, 40, 99-106 [in Ukrainian].

6. Zheleznjak, K.L. (2015). Mekhanizm formuvannja strateghiji prosuvannja transportnykh poslugh pidpryjemstv [The mechanism of formation of strategy of advancement of transport services of the enterprises]. Extended abstract of candidate's thesis. Kyiv: Natsionalnyi transportnyi universytet [in Ukrainian].

7. Zhovnovach, R.I. (2016). Upravlinnja konkurentospromozhnistju pidpryjemstv siljsjkoghospodarsjkogho mashynobuduvannja [Management of competitiveness of agricultural machinery enterprises]. Doctor's thesis. Mariupolj: DVNZ «Pryazovsjkyj derzhavnyj tekhnichnyj universytet» [in Ukrainian].

8. Kindij, M.V., \& Malysh, Ja.V. (2014). Chynnyky ta jikh vplyv na formuvannja taryfiv na mizhnarodni vantazhni avtomobiljni perevezennja [Factors and their influence on the formation of tariffs for international road haulage]. Visnyk Nacionaljnogho universytetu «Ljvivsjka politekhnika». Loghistyka - Bulletin of the National University «Lviv Polytechnic». Logistics, 811, 156-161 [in Ukrainian].

9. Kozina, K.Gh. (2015). Analiz rynku mizhnarodnykh avtotransportnykh vantazhnykh perevezenj: suchasnyj stan ta perspektyvy rozvytku [Analysis of the market of international road freight transport: current status and prospects]. Naukovyj visnyk Mizhnarodnogho ghumanitarnogho universytetu. Serija: Ekonomika $i$ menedzhment - Scientific Bulletin of the International Humanities University. Series: Economics and Management, 10, 134-138 [in Ukrainian].

10. Kozina, K.Gh. (2020). Ocinjuvannja stanu ta rozvytok reghionaljnykh rynkiv vantazhnykh avtotransportnykh perevezenj [Assessment of the state and development of regional markets of freight road transport]. Extended abstract of candidate's thesis. Ivano-Frankivsjk: State University «Precarpathian National University. Vasily Stefanik» [in Ukrainian].

11. Kozina, K.Gh. (2014). Teoretyko-metodychni osnovy faktornogho analizu konkurentospromozhnosti mizhnarodnykh avtotransportnykh vantazhnykh perevezenj Ukrajiny [Theoretical and methodological bases of factor analysis of competitiveness of international road freight transportation of Ukraine]. Naukovyj visnyk Khersonsjkogho derzhavnogho universytetu. Serija: Ekonomichni nauky Scientific Bulletin of Kherson State University. Series: Economic Science, 6(2), 203206 [in Ukrainian].

12. Maksjuta, M.S., \& Djachenko, T.O. (2020). Osoblyvosti upravlinnja konkurentospromozhnistju na transportnykh pidpryjemstvakh. Innovacijni rishennja $v$ suchasnij nauci, osviti ta praktyci: Materialy I Mizhnarodnoji naukovopraktychnoji internet-konferenciji (naukove vydannja). Kyiv: Nacionaljnyj transportnyj universytet, 1, 216-219 [in Ukrainian].

13. Mitchenko, Gh.V. (2015). Orghanizacijno-ekonomichne zabezpechennja strateghichnogho marketynghu na pidpryjemstvakh avtomobiljnogho transport [Organizational and economic support of strategic marketing at road transport enterprises]. Candidate's thesis. Kyiv: Nacionaljnyj transportnyj universytet [in Ukrainian].

14. Nykyforuk, O.I., Stasjuk, O.M., Chmyrjova, L.Ju., \& Fedjaj, N.O. (2019). Cyfrovizacija $\mathrm{v}$ transportnomu sektori: tendenciji ta indykatory rozvytku. Chastyna 1 [Digitization in the transport sector: trends and indicators of development. Part 1]. 
Statystyka Ukrajiny - Statistics of Ukraine, 3, 70-81 [in Ukrainian].

15. Nykyforuk, O.I., Stasjuk, O.M., Chmyrjova, L.Ju., \& Fedjaj, N.O. (2019). Cyfrovizacija v transportnomu sektori: tendenciji ta indykatory rozvytku. Chastyna 2 [Digitization in the transport sector: trends and indicators of development. Part 2]. Statystyka Ukrajiny - Statistics of Ukraine, 4, 48-64 [in Ukrainian].

16. Ponomarjov, A.M. (2012). Vyznachennja osnovnykh parametriv marketynghu ta loghistyky pry funkcionuvanni ATP na rynku mizhnarodnykh vantazhnykh perevezenj [Determining the main parameters of marketing and logistics in the functioning of ATP in the international freight market]. Problemy i perspektyvy rozvytku pidpryjemnyctva - Problems and prospects of entrepreneurship development, 2, 45-49 [in Ukrainian].

17. Ponomarjova, N.M., \& Ponomarjov, A.M. (2012). Teoretychni aspekty autsorsinghu $\mathrm{u}$ sferi mizhnarodnykh avtomobiljnykh vantazhnykh perevezenj [Theoretical aspects of outsourcing in the field of international road haulage]. Problemy $i$ perspektyvy rozvytku pidpryjemnyctva - Problems and prospects of entrepreneurship development, 1, 61-65 [in Ukrainian].

18. Ponomarjova, N.M., \& Ponomarjov, A.M. (2011). Formuvannja mekhanizmu vzajemodiji avtotransportnogho pidpryjemstva iz subjektamy rynku mizhnarodnykh vantazhnykh perevezenj [Formation of the mechanism of interaction of the motor transport enterprise with subjects of the market of the international freight transportations]. Marketyngh i menedzhment innovacij - Marketing and innovation management, 4 (1), 196-201 [in Ukrainian].

19. Snizhko, L.L., \& Ghlavacjkyj, P.V. (2011). Vyznachennja ta ocinka chynnykiv, shho vplyvajutj na rivenj konkurentospromozhnosti ukrajinsjkykh pidpryjemstv v sferi mizhnarodnykh avtomobiljnykh perevezenj [Identification and assessment of factors influencing the level of competitiveness of Ukrainian enterprises in the field of international road transport]. Upravlinnja proektamy, systemnyj analiz i loghistyka. Tekhnichna serija - Project management, systems analysis and logistics. Technical series, 8, 354-359 [in Ukrainian].

20. Transportna strateghija Ukrajiny na period do 2030 roku [Transport strategy of Ukraine for the period up to 2030]. zakon.rada.gov.ua. Retrieved from: https://zakon.rada.gov.ua/laws/show/430-2018-\%D1\%80\#Text [in Ukrainian].

21. Janovsjka, V.P., \& Kyrychenko, Gh.V. (2020). Osoblyvosti formuvannja strateghiji rozvytku nacionaljnykh avtotransportnykh pereviznykiv [Features of formation of strategy of development of national motor carriers]. Menedzhment ta pidpryjemnyctvo $v$ Ukrajini: etapy stanovlennja ta problemy rozvytku - Management and entrepreneurship in Ukraine: stages of formation and problems of development, 2, 2, 92-108 [in Ukrainian].

\section{Відомості про авторів}

ДМИТРІВ Дмитро Володимирович - кандидат технічних наук, доцент, завідувач кафедри економічної кібернетики, Тернопільський національний технічний університет імені Івана Пулюя (46006, м. Тернопіль, вул. Руська, 56, e-mail: dmytrivd75@gmail.com).

ДМИТРІВ Олена Романівна - кандидат технічних наук, доцент кафедри 
автоматизації технологічних процесів i виробництв, Тернопільський національний технічний університет імені Івана Пулюя (46006, м. Тернопіль, вул. Руська, 56, e-mail: rogatynska_o@ukr.net).

ДЕНКЕВИЧ Марія-Мар'яна Михайлівна - магістрантка першого року навчання факультету економіки та менеджменту, Тернопільський національний технічний університет імені Івана Пулюя (46006, Тернопіль, вул. Руська, 56, e-mail: maryana_denkevych@ukr.net).

DMYTRIV Dmytro - Candidate of Technical Sciences, Associate Professor, Head of Department of Economic Cybernetics, Ternopil Ivan Puluj National Technical University (46001, Ternopil, 56, Ruska Str., e-mail: dmytrivd75@gmail.com).

DMYTRIV Olena - Candidate of Technical Sciences, Associate Professor, Department of Automation of Technological Processes and Production, Ternopil Ivan Puluj National Technical University (46001, Ternopil, 56, Ruska Str., e-mail: rogatynska_o@ukr.net).

DENKEVYCH Mariia-Mariana - First Year Master's Student of the Faculty of Economics and Management, Ternopil Ivan Puluj National Technical University (46001, Ternopil, 56, Ruska Str., e-mail: maryana_denkevych@ukr.net).

ДМЫТРИВ Дмитрий Владимирович - кандидат технических наук, доцент, заведующий кафедрой економической кибернетики, Тернопольський нацыональний технический университет имени Ивана Пулюя (46006, г. Тернополь, ул. Руська, 56, e-mail: dmytrivd75@gmail.com).

ДМЫТРИВ Елена Романовна - кандидат технических наук, доцент кафедры автоматизации технологических процессов и производств, Тернопольский национальный технический университет имени Ивана Пулюя (46006, г. Тернополь, ул. Руська, 56, e-mail: rogatynska_o@ukr.net).

ДЕНКЕВИЧ Мария-Марьяна Михайловна - магистрантка первого года обучения факультета економики и менеджмента, Тернопольский национальный технический университет имени Ивана Пулюя (46006, г. Тернополь, ул. Руська, 56, e-mail: maryana_denkevych@ukr.net).

УДК 351.07:005.5 (075.8; 477)

DOI: 10.37128/2411-4413-2021-2-11

ОСОБЛИВОСТІ

ІНФОРМАЦІЙНИХ

СИСТЕМ I

ТЕХНОЛОГІЙ

ПУБЛІЧНОГО

УПРАВЛІННЯ ТА

АДМІНІСТРУВАННЯ В

КОНТЕКСТI

ЄВРОІНТЕГРАЦІЙНИХ

ПРОЦЕСІВ
ГАЛИЧ О.А., кандидат економічний наук, професор, периий проректор

ДЕМИДКІН О.С., здобувач вищої освіти ступеня доктора філософіï кафедри публічного управління та адміністрування, Полтавська державна аграрна академія (м. Полтава) 